九州大学学術情報リポジトリ

Kyushu University Institutional Repository

\title{
A Study on the Community Structure of Subtidal Marine Algae in Kijang, Korea
}

Choi, Ghang Geun

Korea Inter-University Institute of Ocean Science, Pukyong National University

Oh, Seok Jin

Korea Inter-University Institute of Ocean Science, Pukyong National University

Kang, Ik Joon

Aquatic Biomonitoring and Environmental Laboratory, Department of Bioscience and Biotechnology, Faculty of Agriculture, Kyushu University

https://doi.org/10.5109/17798

出版情報：九州大学大学院農学研究院紀要. 55 (1)，pp.39-45，2010-02-26. Faculty of Agriculture， Kyushu University

バージョン :

権利関係 : 


\title{
A Study on the Community Structure of Subtidal Marine Algae in Kijang, Korea
}

\section{Chang Geun CHOI ${ }^{1}$, Seok Jin $\mathrm{OH}^{1}$ and Ik Joon KANG ${ }^{2 *}$}

\author{
Aquatic Biomonitoring and Environmental Laboratory, Department of Bioscience and Biotechnology, \\ Faculty of Agriculture, Kyushu University, Fukuoka 812-8581, Japan \\ (Received November 2, 2009 and accepted November 19, 2009)
}

\begin{abstract}
A subtidal marine benthic algal vegetation at Kijang, the southern east of Korea was investigated to clarify the community structure and the pattern of geographical distribution by a quadrat method along a transect line between February 2006 and January 2007. Total 59 species including 6 of green algae, 14 of brown algae, 39 of red algae were collected and identified. Among these species, 14 species were found throughout the year. Annual mean biomass in wet weight of total vegetation, maximum biomass was recorded in winter and spring seasons, and decreased in summer season. Dominant species was Prionits cornea in terms of biomass, and subdominant species were Phycodrys fimbriata and Gelidium amansii. Coarsely branched form was the most abundant accounting $64.4 \%$ of the total value. Seasonal variations in algal biomass were principally linked to fluctuations in biomass of coarsely branched and thick leathery form algae. The R/P, C/P and $(\mathrm{R}+\mathrm{C}) / \mathrm{P}$ value reflection flora characteristics were $2.79,0.43$ and 3.21, respectively. Two groups produced by cluster analysis, one including sites Duho, Dongbaek and the other including sites Seoam, Mundong, showed meaningful difference in similarity, each other. In conclusion, the number of marine algae species in Kijang was reduced comparing with the previous studies.
\end{abstract}

Keywords: biomass, cluster analysis, coarsely branched, community structure, similarity

\section{INTRODUCTION}

Local marine algal community is often positively influenced by the presence of habitat forming or habitat modifying organisms (Thompson et al., 1996; Bates and DeWreede, 2007). The importance of biogenic habitat provision and of positive interactions in general is increasingly acknowledged, particularly in marine systems (Bertness et al., 1999; Bruno et al., 2003). Biogenic habitat provision is most often investigated as the creation or modification of habitat by one species for a group of other species (Castilla et al., 2004).

In the marine environment, it is possible that global change (e.g. increasing ocean acidification) will combine with local impacts (e.g. nutrient release) to accelerate ecological change across broader areas of coast (Russell et al., 2009). On temperate coasts, the most densely populated coasts of the globe, perennial canopies of algae (e.g. kelp forests) and their associated understory have been replaced by mats of turf-forming algae near expanding human populations that discharge nutrients (Eriksson et al., 2002; Airoldi and Beck, 2007; Connell et al., 2008). These environment changes may be used by organisms as cues to begin or end various activities such as reproduction.

Anthropogenic changes in seaweed diversity and community have been observed in nearshore marine environments from many regions throughout the world.

${ }^{1}$ Korea Inter-University Institute of Ocean Science, Pukyong National University, Busan 608-737, Korea

2 Aquatic Biomonitoring and Environmental Laboratory, Department of Bioscience and Biotechnology, Faculty of Agriculture, Kyushu University, Fukuoka 812-8581, Japan

* Corresponding author (E-mail: kangnew@agr.kyushu-u.ac.jp)
Anthropogenic stressors that result in changes in seaweed assemblages include eutrophication, silt deposition, habitat alienation, and harvest of predators or herbivores (Bates and DeWreede, 2009). These observed changes involve different components of biodiversity, including the number and identity of seaweed species and functional groups. Thus, studies of marine algal flora for any region have not only set out the distributional data concerning each species, but also have provided much valuable ecological information on local communities (Boo and Lee, 1986).

The east and south-east coast of Korea has been attracted attention because of its hydrographical and biological distinctness and inclusively recognized as a temperate region in view of the biogeographical distribution of marine benthic algae by many phycologists (Boo and Lee, 1986; Chung et al., 1991; Choi et al., 2006; Sohn et al., 2007). In east and south-east coasts, many marine algal community studies were focused on intertidal zone (Lee and Oh, 1986; Kang et al., 2008) and a few in subtidal zones. Because of the difficulties and limited of sampling, much valuable information on subtidal marine algae has been obtained by SCUBA diving at several places around Korean coasts (Chung et al., 1991; Choi et al., 2008; Ko et al., 2008).

This paper is prepared for knowledge on the floristic composition and seasonal periodicity of marine algae of the south-east coast of Korea which shows characteristics of typical temperate flora. Study area was selected on the subtidal shore of a Kijang, and the community structure of marine algae was investigated at a study area.

\section{MATERIALS AND METHODS}

The collection and observation of subtidal macroalgae 


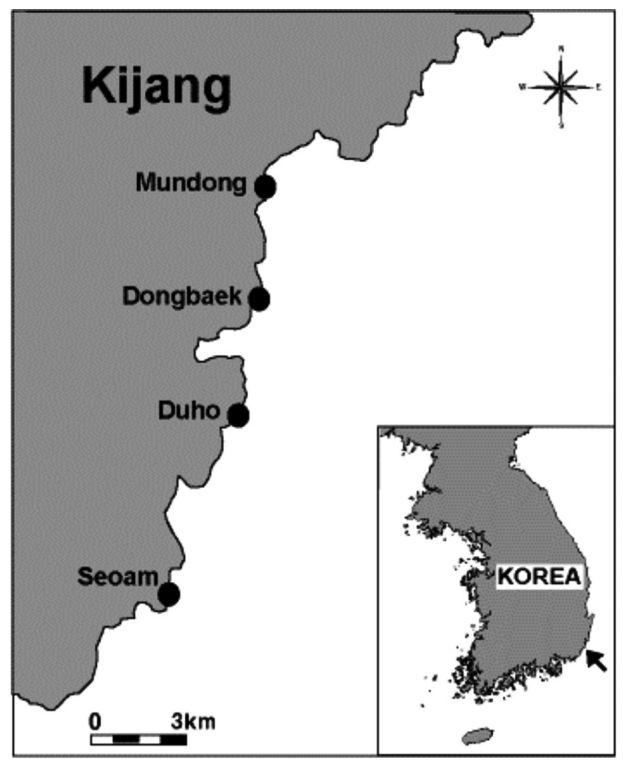

Fig. 1. Map showing the investigated localities.

were carried out at 4 sites chosen as representative areas that were accessible by SCUBA diving during the period from February 2006 to January 2007 (Fig. 1), using a quadrat method along a vertical transect line set across the subtidal zone perpendicularly to the coastal line.

The specimens (excluding crustose forms) were scraped out the substratum using a paint-scraper and placed in numbered fine-mesh bags. All samples were preserved in 5-10\% formalin-seawater solution and transferred to the laboratory for identification. The classification of taxa was followed by Kang (1968) and Lee and Kang $(1986,2001)$. They were washed and cleaned to sort species to measure fresh weight per $\mathrm{m}^{2}$.

In order to analyze floristic composition value of the vegetations, C/P (Segawa, 1956), R/P (Feldmann, 1937), and $(\mathrm{R}+\mathrm{C}) / \mathrm{P}$ (Cheney, 1977) ratio were adopted. The similarity of flora was compared to group-average using PRIMER (Plymouth Routines Multivariate Ecological Research) computer package when the data consists of species presence-absence data (Clarke and Gorley, 2006).

\section{RESULTS}

A total of 59 taxa are recorded in seasonally survey during the period, as listed in Table 1 and 2; 6 Chlorophyta, 14 Phaeophyta and 39 Rhodophyta. The numbers of brown algae are the highest from winter to spring season, whereas the numbers of red algae are the highest in summer and autumn season (Table 1). The largest number of marine algal species was found at Mundong throughout the study period. On the other hand, the smallest number of species was found from 6 (autumn) to 21 (summer) at Duho area (Table 2). The seasonal occurrence of the algae changes markedly through the year. The seasonal patterns of total numbers of species found at each site are shown in Table 2. Seasonal occurrences of these species were 35, 40, 36 and 31 for winter, spring, summer and autumn, respectively. Numbers of macroalgal species showed highest at spring, minima were recorded at autumn.

Fourteen species found at all four seasons throughout all study area. They are Ulva pertusa of green algae, Ecklonia cava of brown algae, and Gelidium amansii, Lithophyllum okamurae, Corallina pilulifera, Prionitis cornea, Plocamium telfairiae,

Table 1. A list of marine algal species found at study sites

\begin{tabular}{|c|c|c|c|c|c|c|c|c|c|c|c|c|c|c|c|c|}
\hline \multirow{2}{*}{ Species } & \multicolumn{4}{|c|}{ Winter } & \multicolumn{4}{|c|}{ Spring } & \multicolumn{4}{|c|}{ Summer } & \multicolumn{4}{|c|}{ Autumn } \\
\hline & $\mathrm{SA}$ & $\mathrm{DH}$ & $\mathrm{DB}$ & $\mathrm{MD}$ & $\mathrm{SA}$ & $\mathrm{DH}$ & $\mathrm{DB}$ & $\mathrm{MD}$ & $\mathrm{SA}$ & $\mathrm{DH}$ & $\mathrm{DB}$ & $\mathrm{MD}$ & $\mathrm{SA}$ & $\mathrm{DH}$ & $\mathrm{DB}$ & $\mathrm{MD}$ \\
\hline \multicolumn{17}{|l|}{ Chlorophyta } \\
\hline Enteromorpha linza & & & & & + & & & & & & & & & & & \\
\hline Ulva pertusa & + & + & + & + & + & + & + & + & + & + & + & + & + & + & + & + \\
\hline Cladophora sakaii & & & & & & & & & & + & + & & & & & \\
\hline Bryopsis plumosa & & & & & & & + & & + & & & & + & & & \\
\hline Codium adhaerens & + & & + & + & + & + & & & + & + & + & & & & & \\
\hline Codium fragile & + & & & & & & & & & & & & & & & \\
\hline \multicolumn{17}{|l|}{ Phaeophyta } \\
\hline Colpomenia sinuosa & + & + & + & + & + & & + & + & & & & & & & & + \\
\hline Undaria pinnatifida & + & + & + & + & & & + & + & & & & & & & & \\
\hline Ecklonia cava & & & & + & & & & + & + & & + & + & & & & + \\
\hline Ecklonia stolonifera & & & & + & & & & + & & & & & & & & \\
\hline Dictyopteris latiuscula & & & & & & & & & & & & & & & & + \\
\hline Dictyopteris prolifera & & & & + & + & & + & + & & & + & & & & & \\
\hline Dictyota dichotoma & & & & & & & & & & + & + & & & & & \\
\hline Dilophus okamurae & & & & + & & + & + & + & & & + & & & & & \\
\hline Padina arborescens & & & & + & & & + & + & & & & & & & & \\
\hline Sargassum fulvellum & + & & & + & & & & + & & & & & & & & \\
\hline
\end{tabular}

*SA: Seoam, DH: Duho, DB: Dongbaek, MD: Mundong. 
Table 1. (Continued)

\begin{tabular}{|c|c|c|c|c|c|c|c|c|c|c|c|c|c|c|c|c|}
\hline \multirow{2}{*}{ Species } & \multicolumn{4}{|c|}{ Winter } & \multicolumn{4}{|c|}{ Spring } & \multicolumn{4}{|c|}{ Summer } & \multicolumn{4}{|c|}{ Autumn } \\
\hline & SA & $\mathrm{DH}$ & DB & $\mathrm{MD}$ & SA & $\mathrm{DH}$ & $\mathrm{DB}$ & $\mathrm{MD}$ & $\mathrm{SA}$ & $\mathrm{DH}$ & $\mathrm{DB}$ & $\mathrm{MD}$ & SA & $\mathrm{DH}$ & $\mathrm{DB}$ & MD \\
\hline Sargassum giganteifolium & & & & & & & & & & & & + & & & & \\
\hline Sargassum horneri & + & & & & + & + & + & + & & & & & + & + & & + \\
\hline Sargassum macrocarpum & & & & & & & & & & & & + & & & & \\
\hline Sargassum ringgoldianum & & & & & & & & + & & & & + & & & & \\
\hline \multicolumn{17}{|l|}{ Rhodophyta } \\
\hline Scinaia japonica & & & & & & & & + & & & & & & & & \\
\hline Gelidium amansii & + & + & + & + & + & + & + & + & + & + & + & + & + & & + & + \\
\hline Pterocladia capillacea & & & & & + & & & & & + & + & & & & + & \\
\hline Peyssonelia caulifera & & & & & & & & & + & & & + & + & & & \\
\hline Hildenbrandtia rubra & & & & & + & + & + & + & + & + & + & + & & & & + \\
\hline Lithophyllum okamurae & & + & + & + & + & & + & & + & + & & & + & & & + \\
\hline Lithothamnion cystocarpioideum & & & & & + & + & + & + & + & + & & + & & & & \\
\hline Porolithon colliculosum & & & & & & & & & + & + & & + & & & & \\
\hline Amphiroa beauvoisii & & & & & & & & & + & & & & & & & + \\
\hline Amphiroa dilatata & & & & + & & + & + & + & & & + & & & & & \\
\hline Corallina officinalis & & & & & & & & + & & & & + & & & & \\
\hline Corallina pilulifera & + & & + & + & + & + & + & & + & + & + & + & + & & + & + \\
\hline Prionitis cornea & + & + & + & + & + & + & + & + & + & + & + & & + & & + & + \\
\hline Grateloupia elliptica & + & + & + & + & + & + & + & + & + & + & + & + & & & & \\
\hline Grateloupia turuturu & & & + & + & & & & & & & & & + & & & \\
\hline Halymeniopsis dilatata & & & & & & & & & & & + & + & & & & \\
\hline Chondrococcus hornemanni & & & & & & & & & & & & & + & & & + \\
\hline Plocamium telfairiae & + & + & + & + & & + & + & + & + & & + & + & + & + & + & + \\
\hline Phacelocarpus japonicus & & + & & & + & + & & & + & & & + & & & & \\
\hline Gracilaria textorii & + & & + & + & & + & + & + & & & & & & & & \\
\hline Ahnfeltiopsis flabelliformis & & & & & + & & & & & & & & & & + & \\
\hline Chondrus crispus & & & & & & & & & & & & & & & + & \\
\hline Chondrus ocellatus & & & & + & & & + & & + & + & + & + & & & & \\
\hline Chondracanthus intermedia & & & & + & + & + & + & + & + & + & + & + & & & + & \\
\hline Chondracanthus tenellus & & & + & + & & & + & + & + & + & + & + & + & & & \\
\hline Rhodymenia intricata & + & & + & & + & + & + & + & + & + & + & + & + & & + & \\
\hline Lomentaria catenata & & & + & + & + & & + & + & + & + & + & + & + & & + & \\
\hline Ceramiopsis japonica & & & & + & & & & & & & & & & & & \\
\hline Acrosorium polyneurum & & + & + & + & & + & + & + & & + & + & + & + & & + & + \\
\hline Acrosorium uncinatum & & & & & + & & + & & & & & & & & & \\
\hline Acrosorium yendoi & & + & + & & & & & & & & & & & & & \\
\hline Phycodrys fimbriata & + & + & + & + & + & + & + & & & + & & + & & + & + & \\
\hline Heterosiphonia japonica & + & & & & & & & & & & & & & & & + \\
\hline Chondria crassicaulis & + & & & & + & & + & & & & & & & & & + \\
\hline Laurencia pinnata & & & & & & & & & + & & & & + & & & + \\
\hline Polysiphonia morrowii & & & & & & & & + & & & & & & & & + \\
\hline Polysiphonia yendoi & & & & + & & & & & & & & & & & & \\
\hline Symphyocladia latiuscula & & & & & & & & & & & & & & + & & \\
\hline Melobesioidean algae & + & + & + & + & + & + & + & + & + & + & + & + & + & + & + & + \\
\hline
\end{tabular}

*SA: Seoam, DH: Duho, DB: Dongbaek, MD: Mundong.

Table 2. Marine algal and floristic composition at study sites

\begin{tabular}{|c|c|c|c|c|c|c|c|c|c|c|c|c|c|c|c|c|c|}
\hline \multirow{2}{*}{ Species } & \multicolumn{4}{|c|}{ Winter } & \multicolumn{4}{|c|}{ Spring } & \multicolumn{4}{|c|}{ Summer } & \multicolumn{4}{|c|}{ Autumn } & \multirow{2}{*}{ Total } \\
\hline & SA & $\mathrm{DH}$ & DB & MD & SA & DH & DB & MD & SA & DH & DB & MD & SA & $\mathrm{DH}$ & DB & MD & \\
\hline Chlorophyta & 3 & 1 & 2 & 2 & 3 & 2 & 2 & 1 & 3 & 3 & 3 & 1 & 2 & 1 & 1 & 1 & 6 \\
\hline Phaeophyta & 4 & 2 & 2 & 8 & 3 & 2 & 6 & 10 & 1 & 1 & 4 & 4 & 1 & 1 & 0 & 4 & 14 \\
\hline Rhodophyta & 11 & 10 & 15 & 18 & 17 & 15 & 20 & 17 & 19 & 17 & 16 & 19 & 14 & 4 & 13 & 14 & 39 \\
\hline Sum & 18 & 13 & 19 & 28 & 23 & 19 & 28 & 28 & 23 & 21 & 23 & 24 & 17 & 6 & 14 & 19 & 59 \\
\hline
\end{tabular}


Chondracanthus intermedia, C. tenellus, Rhodymenia intricate, Lomentaria catenata, Acrosorium polyneurum, Phycodrys fimbriata and Melobesioidean algae of red algae.

The average biomass ( $\mathrm{g}$ fresh weight $\mathrm{m}^{-2}$ ) of algal community measured throughout the survey periods (Table 3). Mean biomass of marine algal species showed different according to the stations and seasons. The dominant species for biomass at Seoam and Dongbaek were Phycodrys fimbriata, while at Duho and Mundong were

Table 3. Seasonal mean biomass (fresh weight $\mathrm{g} \mathrm{m}^{-2}$ ) of algal species at study sites

\begin{tabular}{|c|c|c|c|c|c|c|c|c|c|c|c|c|c|c|c|c|}
\hline \multirow{2}{*}{ Species } & \multicolumn{4}{|c|}{ Winter } & \multicolumn{4}{|c|}{ Spring } & \multicolumn{4}{|c|}{ Summer } & \multicolumn{4}{|c|}{ Autumn } \\
\hline & $\mathrm{SA}$ & $\mathrm{DH}$ & $\mathrm{DB}$ & $\overline{\mathrm{MD}}$ & $\mathrm{SA}$ & $\mathrm{DH}$ & $\mathrm{DB}$ & $\mathrm{MD}$ & $\mathrm{SA}$ & $\mathrm{DH}$ & $\mathrm{DB}$ & $\mathrm{MD}$ & $\mathrm{SA}$ & $\mathrm{DH}$ & $\mathrm{DB}$ & $\mathrm{MD}$ \\
\hline \multicolumn{17}{|l|}{ Chlorophyta } \\
\hline Ulva pertusa & 22.8 & 0.4 & 0.8 & 2.4 & 0.4 & 1.2 & 8.4 & 0.4 & 8.0 & & 2.0 & 2.0 & 6.4 & 0.4 & 14.4 & 10.8 \\
\hline Bryopsis plumosa & & & & & & & & & 0.4 & & & & 0.4 & & & \\
\hline Codium fragile & 2.0 & & & & & & & & & & & & & & & \\
\hline \multicolumn{17}{|l|}{ Phaeophyta } \\
\hline Colpomenia sinuosa & & & & 53.6 & & & 1.2 & 0.4 & & & & & & & & 0.4 \\
\hline Ecklonia cava & & & & & & & & 164.4 & & & & 99.6 & & & & 174.0 \\
\hline Dictyopteris latiuscula & & & & & & & & & & & & & & & & 61.6 \\
\hline Dictyopteris prolifera & & & & 323.6 & & & & 1026.8 & & & & & & & & \\
\hline Dictyota dichotoma & & & & & & & & & & 10.8 & & & & & & \\
\hline Dilophus okamurae & & & & 37.6 & & & 133.6 & & & & & & & & & \\
\hline Sargassum giganteifolium & & & & & & & & & & & & 44.4 & & & & \\
\hline Sargassum horneri & 186.0 & & & & 783.2 & & & & & & & & 0.4 & 10.0 & & 0.4 \\
\hline \multicolumn{17}{|l|}{ Rhodophyta } \\
\hline Scinaia japonica & & & & & & & & 148.0 & & & & & & & & \\
\hline Gelidium amansii & 0.4 & 2.0 & 43.6 & 3.2 & 91.2 & 29.2 & 107.6 & 9.2 & 253.2 & 308.4 & 136.4 & 13.2 & 40.8 & & 10.0 & 8.8 \\
\hline Pterocladia capillacea & & & & & 0.8 & & & & & & & & & & 6.8 & \\
\hline Peyssonelia caulifera & & & & & & & & & & & & 0.4 & 6.4 & & & \\
\hline Hildenbrandtia rubra & & & & & & & & & & & & & & & & 12.4 \\
\hline Lithophyllum okamurae & & 16.0 & 0.4 & & & & 1.6 & & & & & & 5.6 & & & 6.0 \\
\hline Lithothamnion cystocarpioideum & & & & & & & & & 20.8 & & & 0.4 & & & & \\
\hline Porolithon colliculosum & & & & & & & & & 8.4 & 10.4 & & 4.0 & & & & \\
\hline Amphiroa beauvoisii & & & & & & & & & 3.2 & & & & & & & 19.2 \\
\hline Amphiroa dilatata & & & & 1.2 & & & 0.4 & 0.4 & & & & & & & & \\
\hline Corallina officinalis & & & & & & & & 3.6 & & & & 17.6 & & & & \\
\hline Corallina pilulifera & & & 27.2 & & 0.4 & & & & 2.4 & & & 8.4 & 8.0 & & 8.8 & 304.8 \\
\hline Prionitis cornea & 79.2 & 600.8 & & 1.2 & 90.4 & 22.8 & 314.0 & 167.2 & 177.2 & 218.4 & 274.0 & & 70.8 & & 355.6 & 0.4 \\
\hline Grateloupia elliptica & & & & & 12.4 & & 218.4 & & 217.2 & 20.8 & & & & & & \\
\hline Grateloupia turuturu & & & & 0.8 & & & & & & & & & 6.0 & & & \\
\hline Halymeniopsis dilatata & & & & & & & & & & & 28.0 & 2.8 & & & & \\
\hline Chondrococcus hornemanni & & & & & & & & & & & & & 38.0 & & & 1.2 \\
\hline Plocamium telfairiae & 49.6 & 0.4 & & 10.4 & & 17.6 & & 2.4 & 7.2 & & 0.4 & 2.0 & 49.6 & 0.8 & 28.4 & 343.2 \\
\hline Phacelocarpus japonicus & & 0.4 & & & & 1.6 & & & & & & 1.6 & & & & \\
\hline Gracilaria textorii & 24.0 & & 14.0 & 3.6 & & 31.2 & & 109.6 & & & & & & & & \\
\hline Ahnfeltiopsis flabelliformis & & & & & 0.8 & & & & & & & & & & 7.2 & \\
\hline Chondrus crispus & & & & & & & & & & & & & & & 4.4 & \\
\hline Chondrus ocellatus & & & & 2.4 & & & 53.6 & & 1.6 & 14.0 & & 3.6 & & & & \\
\hline Chondracanthus intermedia & & & & 0.4 & & & 49.2 & & & 2.0 & & & & & 22.8 & \\
\hline Chondracanthus tenellus & & & 1.2 & 28.8 & & & 190.4 & 240.0 & 3.6 & 3.2 & 235.2 & 0.8 & 22.0 & & & \\
\hline Rhodymenia intricata & 30.0 & & 28.2 & & 22.4 & 165.6 & 188.8 & & 78.0 & 147.6 & 18.8 & 16.0 & 0.8 & & 37.2 & \\
\hline Lomentaria catenata & & & & 2.0 & 0.8 & & 22.8 & & 2.0 & 2.0 & 2.0 & 7.6 & 27.6 & & 55.6 & \\
\hline Ceramiopsis japonica & & & & 1.2 & & & & & & & & & & & & \\
\hline Acrosorium polyneurum & & 108.8 & & 16.4 & & 12.8 & 298.4 & 8.8 & & 6.0 & 24.8 & 6.4 & 6.0 & & 63.2 & 29.2 \\
\hline Acrosorium yendoi & & 16.8 & 15.2 & & & & & & & & & & & & & \\
\hline Phycodrys fimbriata & 1133.6 & 495.2 & 68.4 & & 6.0 & 840.8 & & & & & & 62.8 & & 19.2 & 5.6 & \\
\hline Heterosiphonia japonica & 0.8 & & & & & & & & & & & & & & & 1.2 \\
\hline Chondria crassicaulis & 15.2 & & & & & & & & & & & & & & & 3.2 \\
\hline Laurencia pinnata & & & & & & & & & 3.6 & & & & 26.4 & & & 24.0 \\
\hline Polysiphonia morrowii & & & & & & & & 0.8 & & & & & & & & 10.0 \\
\hline Polysiphonia yendoi & & & & 4.4 & & & & & & & & & & & & \\
\hline Symphyocladia latiuscula & & & & & & & & & & & & & & 0.8 & & \\
\hline
\end{tabular}


Table 4. Composition ratio (\%) of macroalgal functional form group investigated at study sites

\begin{tabular}{lrrrrr}
\hline Functional form & Winter & Spring & Summer & Autumn & Total \\
\hline Sheet & 8.6 & 7.5 & 5.6 & 6.5 & 6.8 \\
Coarsely branched & 62.9 & 60.0 & 58.3 & 67.7 & 64.4 \\
Thick leathery & 17.1 & 15.0 & 8.3 & 9.7 & 11.9 \\
Filamentous & 0.0 & 0.0 & 2.8 & 0.0 & 1.7 \\
Jointed calcareous & 5.7 & 7.5 & 11.1 & 6.5 & 6.8 \\
Crustose & 5.7 & 10.0 & 13.9 & 9.7 & 8.5 \\
\hline
\end{tabular}

Table 5. The comparison of value of $\mathrm{R} / \mathrm{P}, \mathrm{C} / \mathrm{P},(\mathrm{R}+\mathrm{C}) / \mathrm{P}$ ratio between the previous studies at the east coast, Korea

\begin{tabular}{lccc}
\hline \multirow{2}{*}{ Reference } & \multicolumn{3}{c}{ Flora characteristics ratio } \\
\cline { 2 - 4 } & $\mathrm{R} / \mathrm{P}$ & $\mathrm{C} / \mathrm{P}$ & $(\mathrm{R}+\mathrm{C}) / \mathrm{P}$ \\
\hline Lee et al. (1997) & 2.92 & 0.54 & 3.46 \\
Nam and Kim (1999) & 2.19 & 0.50 & 2.69 \\
Yoo (2003) & 2.76 & 0.35 & 3.12 \\
Choi (2007) & 2.33 & 0.48 & 2.81 \\
Kang et al. (2008) & 4.47 & 0.59 & 5.06 \\
This study & 2.79 & 0.43 & 3.21 \\
\hline
\end{tabular}

Prionitis cornea and Dictyopteris prolifera in winter, respectively. Prionitis cornea of red algae was $314.0 \mathrm{~g}$ $\mathrm{m}^{-2}$ in spring, $274.0 \mathrm{~g} \mathrm{~m}^{-2}$ in summer and $355.6 \mathrm{~g} \mathrm{~m}^{-2}$ in autumn at Dongbaek respectively, so that it was the highest in autumn and the lowest in summer. The biomass differed according to the seasons at all sites and the increased gradually during the winter and spring seasons, and decreased in summer season.

In case of biomass, the algal community of study area was dominated by Gelidium amansii, Prionitis cornea, Plocamium telfairiae, Rhodymenia intricate and Acrosorium polyneurum throughout the year, and subdominated by Gracilaria textorii and Phycodrys fimbriata in winter and spring, Grateloupia elliptica and Chondracanthus tenellus in summer, and Corallina pilulifera in autumn.

Functional form groups (sheet, coarsely branched, thick leathery, filamentous, jointed calcareous and crustose) were observed and fluctuated seasonally at study sites (Table 4). During the survey period, coarsely branched form was the most highest about $64.4 \%$ among the functional form groups. Annual variations were also high mainly in coarsely branched form between 58.3\% and $67.7 \%$, respectively. The mean biomass of coarsely branched form marine algae was greater throughout the study period than other functional form groups (Table 3). In case of thick leathery form, proportion was observed between $8.3 \%$ and $17.1 \%$ according to the season, respectively. However, seasonal proportion of the other group marine algae fluctuated within 15\% during the study period. These results indicate that seasonal variations in proportion were principally linked to fluctuations in proportion of coarsely branched and thick leathery form marine algae.

The comparison of value of $\mathrm{R} / \mathrm{P}, \mathrm{C} / \mathrm{P}$, and $(\mathrm{R}+\mathrm{C}) / \mathrm{P}$

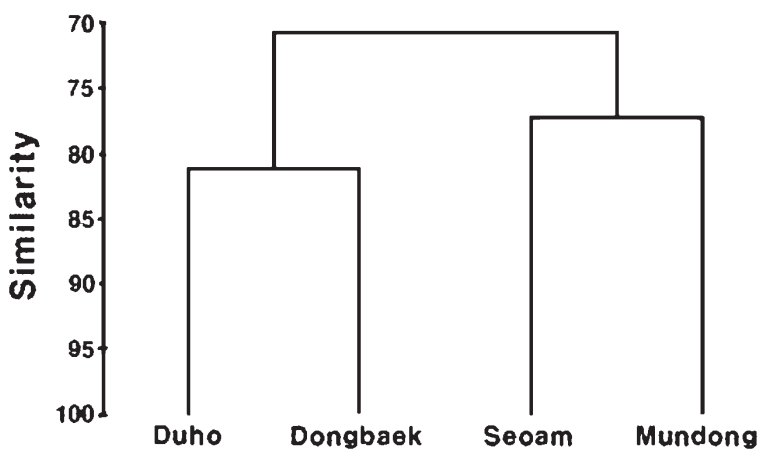

Fig. 2. A dendrogram produced by clustering location flora using average linkage at 4 sampling sites at Kijang.

ratio during the study period at Kijang coast was given in Table 5. A total of 59 taxa are recorded in seasonally survey during the period, as listed in Table $1 ; 6$ green, 14 brown and 39 red algae. The $\mathrm{C} / \mathrm{P}$ value ranges from 0.33 in winter to 0.57 in summer and 0.43 in total at study sites. Thus, the $\mathrm{R} / \mathrm{P}, \mathrm{C} / \mathrm{P}$, and $(\mathrm{R}+\mathrm{C}) / \mathrm{P}$ value were 2.79 , 0.43 , and 3.21 in this survey, respectively.

The dendrograms by clustering seasonally flora on the basis of the similarities of the species composition are shown in Fig. 2. Community structure of subtidal marine algae could be divided into two groups on $70 \%$ level of threshold. In view of marine algae composition, the first group in Duho and Dongbaek can be represents the characteristics on 80\% level of similarity, as shown in Fig. 2. The representative species in this site are Cladophora sakaii, Codium adhaerens, Dictyota dichotoma, Dilophus okamurae, Pterocladia capillaceae and Acrosorium yendoi. The second group represents the characteristics of Seoam and Mundong site flora. The typical species in Seoam and Mundong are Colpomenia sinuosa, Ecklonia cava, Ecklonia stolonifera, Padina arborescens, Sargassum fulvellum, Sargassum ringgoldianum, Peyssonnelia caulifera, Phacelocarpus japonicas, Chondria crassicaulis and Laurencia pinnata. Based on these comparisons, brown algae were absolutely representation the second group such as Seoam and Mundong flora rather than the first group (Duho and Dongbaek).

\section{DISCUSSION}

In general, marine algae were divided into three groups; 1) species occurred in the cold current area, 2) species occurred in the warm current area, and 3) species occurred commonly in both of the areas (Notoya and 
Aruga, 1989). This study area is belonged to the Southern East Coast Section by Kang (1966). A total of 59 species was identified during the present investigation. Among this present species, marine algae mainly represented in the warm current area and commonly in both of the areas. Sargassaceous plants mainly occurred in the warm current area; Ecklonia cava, Ecklonia stolonifera, Sargassum fulvellum, Sargassum macrocarpum and Sargassum ringgoldianum. Ecklonia spp. is included in the warm current species even though it belongs to the Laminariales. Undaria pinnatifida and Sargassum horneri were found at commonly in both of the areas.

The flora and community structure of benthic marine algae in Ilkwang Bay near this study sites (Kang et al., 2008) reported that the subtidal vegetation is dominated by Enteromorpha linza, Ulva pertusa, Ecklonia cava, Sargassum thunbergii, Amphiroa anceps, Corallina pilulifera, Gelidium amansii, Chondracanthus tenellus, Chondrus ocellatus, Hypnea charoides, Ahnfeltiopsis flabelliformis, Grateloupia elliptica, Grateloupia filicina, Grateloupia lanceolata, Prionitis cornea, Plocamium telfairiae, Champia parvula, Acrosorium yendoi and Symphyocladia latiuscula. In this study, we found representation species throughout all survey area by Ulva pertusa, Ecklonia cava, Gelidium amansii, Lithophyllum okamurae, Corallina pilulifera, Prionitis cornea, Plocamium telfairiae, Chondracanthus intermedia, C. tenellus, Rhodymenia intricate, Lomentaria catenata, Acrosorium polyneurum, Phycodrys fimbriata and Melobesioidean coralline algae. These results indicate that the dominant species similar compare with previous study (Kang et al., 2008) and this survey results. Due to the plenty of results on the other subtidal studies in southern east coasts of Korea.

Kang et al. (2008) suggested the biomass proportion of marine algae in Ilkwang Bay were fewer about $478.3 \mathrm{~g}$ wet weight $\mathrm{m}^{-2}$ than previous studies (Lee et al., 1984; Nam and Kim, 1999) including the present results (Table 3). Compare with previous study (Lee et al., 1984; Nam and Kim, 1999; Choi, 2007), number of species were similar or decrease each other in total and respective division. Recently, global climate and anthropogenic changes in marine algae diversity as a driver of ecological patterns across local through biogeographic scales has long been of legitimate concern to ecology (Bates et al., 2007; Choi, 2007; Russell et al., 2009). Therefore, the currently observed decrease of marine algal species and reduced biomass is likely to be exacerbated under future climates, human activities and anthropogenic changes in coastal areas.

Marine algal species and biomass is affected by the functional group of dominant marine algae (Littler and Littler, 1984; Wan et al., 2009). In general, marine algal biomass is greater at the community with brown algae such as Laminariales and Sargassaceous plants as dominant algae than green and red algae (Prathep, 2005). The algal biomass of southern east and mid east coast (Nam, 1986; Chung et al., 1991; Kang et al., 2008) is influenced severely by the large brown algae in the community. In particular, biomass of Myagropsis myagroides and Sargassum horneri were high in autumn and winter season at Ilkwang Bay (Kang et al., 2008). In our study, Dictyopteris prolifera, Sargassum horneri, Prionitis cornea and Phycodrys fimbriata were dominant species of biomass during the survey period. Thus, this study sites may result from dominant seaweeds with biomass in brown and red algae and coarsely branched group algae. Sohn (1987) reported that sheet and filamentous form marine algae are common at shallow and high turbid coastal areas, and coarsely branched and thick leathery form are dominant at off shore coastal areas in Korea. In this study, coarsely branched and thick leathery form marine algae were the major group in species number and biomass throughout the survey period. The dominant of coarsely branched form species could relate to the marine environmental condition of this study sites such as off shore coastal areas according to the Sohn (1987).

Michanek (1979) divided the temperate region into cold and warm temperate and explained that the cold temperate region showed a strong seasonality and highest developed kelp such as Laminariales. He mentioned that the east coast of Korea was included to this region (Chung et al., 1991). Boo and Lee (1986) studied seasonal periodicity of algal community, using $\mathrm{R} / \mathrm{P}$ ratio as a function for monthly change of the flora at the rocky shore. Distribution of marine algae was influenced by environmental condition such as the temperate of seawater (Druehl, 1981). Thus, in order to characterize the flora, $\mathrm{R} / \mathrm{P}, \mathrm{C} / \mathrm{P}$ and $(\mathrm{R}+\mathrm{C}) / \mathrm{P}$ ratios were applied by many phycologists (Feldmann, 1937; Cheney, 1977; Segawa, 1956). Boo and Lee (1986) mentioned that the ratios were varied from 1.44 to 3.10 according to the months. Among these three ratios, $\mathrm{R} / \mathrm{P}, \mathrm{C} / \mathrm{P}$ and $(\mathrm{R}+\mathrm{C}) / \mathrm{P}$ ratio calculated 2.79, 0.43 and 3.21, respectively (Table 5). These ratios very similar compare with previous study and this survey results. As a result, the area represented a mixed flora of the cold and warm temperate regions.

Factor such as temperature and daylength have been shown to influence reproduction in temperate seaweed species (Dring, 1982), and other factors such a salinity, substratum and wave action are also primarily important in determining local distribution and abundance of communities (Dawes, 1981; Chung et al., 1991). On the characteristics of algal vegetation, Kang et al. (2008) reported that the brown algae played the role in change of algal vegetation through their biomass and substratum was an important ecological factor at Ilkwang Bay.

In the present study it was found that algal species and substratum condition became a main factor determining the cluster analysis grouping. It is recognized that these results are caused by the two major floral groups at position due to number of species and substratum in survey sites.

\section{REFERENCES}

Airoldi, L. and M. W. Beck 2007 Loss, status and trends for coastal marine habitats of Europe. Ocean. Mar. Biol.: An Ann. Rev., 45: $345-405$ 
Bates, C. R. and R. E. DeWreede 2007 Do changes in seaweed biodiversity influence associated invertebrate epifauna? J. Exp. Mar. Biol. Ecol., 344: 206-214

Bertnes, M. D., G. H. Leonard, J. M. Levine, P. R. Schmidt and A. O. Ingraham 1999 Testing the relative contribution of positive and negative interactions in rocky intertidal communities. Ecol., 80: 2711-2726

Boo, S. M. and I. K. Lee 1986 Studies on benthic algal community in the East coast of Korea. 1. Floristic composition and periodicity of a Sokcho rocky shore. Korean J. Phycol., 1: 107-116

Brono, J. F., J. J. Stachowicz and M. D. Bertness 2003 Inclusion of facilitation into ecological theory. Trends Ecol. Evol., 18: $119-125$

Castilla, J. C., N. A. Lagos and M. Cerda 2004 Marine ecosystem engineering by the alien ascidian Pyura praeputialis on a midintertidal rocky shore. Mar. Ecol. Prog. Ser., 268: 119-130

Cheney, D. P. 1977 R \& C/P - A new and improved ratio for comparing seaweed floras. Suppl. J. Phycol., 13: 129

Choi, C. G. 2007 Algal flora and Ecklonia stolonifera Okamura (Laminariaceae) population of Youngdo in Busan, Korea. Algae, 22: 313-318

Choi, C. G., J. H. Kim and I. K. Chung 2008 Temporal variation of seaweed biomass in Korean coasts: Yokjido, Gyeongnam Province. Algae, 23: 311-316

Choi, C. G., S. N. Kwak and C. H. Sohn 2006 Community structure of subtidal marine algae at Uljin on the East coast of Korea. Algae, 21: 463-470

Chung, H. S., H. J. Lee and I. K. Lee 1991 Vertical distribution of marine algae on a Gallam rocky shore of the mid-east coast of Korea. Korean J. Phycol., 6: 55-67

Clarke, K. R. and R. N. Gorley. 2006 PRIMER V6: User Manual/ Tutorial. PRIMER-E Ltd, Plymouth, p. 190

Connell, S. D., B. D. Russell and D. J. Turner 2008 Recovering a lost baseline: missing kelp forests from a metropolitan coast. Mar. Ecol. Prog. Ser., 360: 63-72

Dawes, C. J. 1981 Marine botany. John Wiley \& Sons, New York, p. 628

Dring, M. J. 1982 The biology of marine plants. Edward Arnold, London, p. 199

Druehl, L. P. 1981 Geographic distribution. In "The Biology of Seaweeds", ed. by C. R. Lobban and M. J. Wynne, Blackwell Sci. Publ., Boston, p. 306-325

Eriksson, B. K., G. Johansson and P. Snoeijs 2002 Long-term changes in the macroalgal vegetation of the inner Gullmar Fjord, Swedish Skagerrak coast. J. Phycol., 38: 284-296

Feldmann, J. 1937 Recherches sur la vegetation marine de la Miditerranee. La cote des Alberes. Rev. Algol., 10: 1-339

Kang, J. W. 1966 On the geographical distribution of marine algae in Korea. Bull. Pusan Fish. Coll., 7: 1-125

Kang, J. W. 1968 Illustrated encyclopedia of fauna and flora of Korea., Vol. 8, Marine algae. Ministry of Education, Seoul, p. 465

Kang, P. J., Y. S. Kim and K. W. Nam 2008 Flora and community structure of benthic marine algae in Ilkwang Bay, Korea.
Algae, 23: 317-326

Ko, Y. W., G. H. Sung, C. H. Yi, H. H. Kim, D. M. Choi, Y. D. Ko, W. J. Lee, H. B. Koh, J. H. Oak, I. K. Chung and J. H. Kim 2008 Temporal variation of seaweed biomass in Korea coasts: Munseom, Jeju Island. Algae, 23: 295-300

Lee, H. B. and Y. S. Oh 1986 A summer algal vegetation in Youngil Bay, eastern coast of Korea. Korean J. Phycol., 1: 225-240

Lee, I. K., H. S. Kim, C. H. Koh, J. W. Kang, S. Y. Hong, S. M. Boo, I. H. Kim and Y. C. Kang 1984 Studies on the marine benthic communities in inter- and subtidal zone. II. Qualitative and quantitative analysis of the community structure in southeastern coast of Korea. Proc. Coll. Natur. Sci. SNU, 9: 71-126

Lee, I. K. and J. W. Kang 1986 A check list of marine algae in Korea. Korean J. Phycol., 1: 311-325

Lee, S. Y., J. W. Lee and H. B. Lee 1997 Marine benthic algal flora of Youngil Bay and its adjacent areas, the eastern coast of Korea. Algae, 12: 303-311

Lee, Y. P. and S. Y. Kang 2001 A catalogue of the seaweeds in Korea. Cheju National University Press, Cheju, p. 662

Littler, M. M. and D. S. Littler 1984 Relationships between macroalgal functional form groups and substrata stability in a subtropical rocky-intertidal system. Mar. Biol., 74: 13-34

Michanek, G. 1979 Phytogeographic provinces and seaweed distribution. Bot. Mar. 22: 375-391

Nam, K. W. 1986 On the marine benthic algal community of Chuckdo in eastern coast of Korea. Korean J. Phycol., 1 185-202

Nam, K. W. and Y. S. Kim 1999 Benthic marine algal flora and community structure of Yongho-dong area in Pusan, Korea. J. Korean Fish. Soc., 32: 374-384

Notoya, M. and Y. Aruga 1989 Vertical distribution of several species of macroalgae (Phaeophyta) along the coast of Aomori Prefecture, Japan. Korean J. Phycol., 4: 165-170

Prathep, A. 2005 Spatial and temporal variations in diversity and percentage cover of macroalgae at Sirinart marine national park, Phuket Province, Thailand. ScienceAsia, 31: 225-233

Russell, B. D., J. I. Thompson, L. J. Falkenberg and S. D. Connel 2009 Synergistic effects of climate change and local stressors: $\mathrm{CO}_{2}$ and nutrient-driven change in subtidal rocky habitats. Glo. Cha. Biol., 15: 2153-2162

Segawa, S. 1956 Coloured illustrations of the seaweeds of Japan. Hoikusha Publ. Co. Osaka

Sohn, C. H. 1987 Phytogeographical characterization and quantitative analysis of algal communities in Korea. Ph. D. Thesis. Chonnam National University, Kwangju, Korea

Sohn, C. H., C. G. Choi and H. G. Kim 2007 Algal communities and useful seaweed distribution at Gangnung and its vicinity in East coast of Korea. Algae, 22: 45-52

Wan, X. Q., H. H. Park, H. I. Yoo and H. G. Choi 2009 Temporal variations in seaweed biomass and coverage in Korean coasts: Ongdo, Chungnam. Fish. Aqua. Sci., 12: 130-137

Yoo, J. S. 2003 Dynamics of marine benthic community in intertidal zone of Seoam, Busan. J. Korean Soc. Oceanogr., 8 $420-425$ 